\title{
SOMATIC HYBRIDIZATION IN SACCHAROMYCES CEREVISIAE: ANALYSIS OF PRODUCTS OF PROTOPLAST FUSION
}

\author{
by \\ BJØRN EGGERT CHRISTENSEN \\ Department of Physiology, Carlsberg Laboratory, \\ Gamle Carlsberg Vej 10, DK-2500 Copenhagen Valby
}

Keywords: Yeast, spheroplasts, polyethylene glycol, karyogamy, tetrad analysis

\begin{abstract}
Yeast strains of identical mating type were converted into protolasts with snail gut enzymes. Fusion induced with polyethylene glycol gave products in which nutritional requirements had complemented each other. The somatic hybrids were invariably maters and non-sporulators. When the strains differed in non-mendelian markers not used in the selection. these markers were found in the expected parental and recombinant combinations in the fusion products. Fusion products of two strains of mating type $\alpha$ were mated with fusion products of two strains of mating type $a$. Two cycles of sporulation and tetrad analysis of the presumed tetraploid gave a regular distribution of all markers showing that the somatic hybrids were indeed diploids homozygous for mating type. A single exception to the expected segregation was found not to be due to an abnormal chromosome number but is attributed to a gene conversion or a mitotic crossing over.
\end{abstract}

\section{INTRODUCTION}

In the life cycle of Saccharomyces mating plays an important role. Mating and sporulation are the normal processes for the exchange and redistribution of genetic material. Since most brewing strains of Saccharomyces are impaired in these processes, they are not easily subjected to cross-breeding. Mutation breeding is likewise met with difficulties, as most brewing strains are diploid or polyploid.

One possibility for circumventing the sexual inabilities of brewing strains is offered by somatic hybridization through protoplast fusion
(23). Protoplasts (2) or spheroplasts are cells which are completely or partially devoid of their cell wall. When such naked cells are mixed with the surface active agent polyethylene glycol (9), coalescence between the plasmalemmas of two or more cells may take place. Such fusion products are regenerated to normal yeast cells in the same way as protoplasts of single cells ( 12 , $13,14,15,22)$. If karyogamy takes place diploid or polyploid cells are obtained. Finally sporulation or treatment with a haploidising agent $(3,8$, 10) may restore the original chromosome number. 
Table I

Yeast strains used

\begin{tabular}{|c|c|c|}
\hline Strain & Genotype & Source \\
\hline $\mathrm{C} 77-\mathrm{D} 2$ & $a$ his3 leu2 trp [ERYRCAPR] & spore from cross $4116 \mathrm{E} \times 3725 \mathrm{C}$ \\
\hline $\mathrm{D} 273-11 \mathrm{~A}$ & a adel hisl & $\begin{array}{l}\text { Course manual on yeast genetics, Cold Spring } \\
\text { Harbor Laboratory }\end{array}$ \\
\hline D286-2A & a adel hisl & 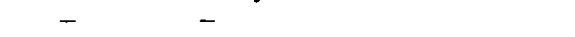 \\
\hline D $517-4 B$ & $a$ ade2 lys 9 & - \\
\hline D585-11C & $a|y s|$ & - \\
\hline D587-4B & $\alpha$ hisl & - \\
\hline $3725 \mathrm{C}$ & $\alpha$ his 3 trp [ERYSCAPR] & - \\
\hline $4116 \mathrm{E}$ & a leu2 [ERYRCAPS] & - \\
\hline$X X a-I-9$ & a his4-864 ade $2-119$ irp 5 a leu 2 ilvl & T. NiLSSON-Tillgiren \\
\hline XXa-III-7 & $\alpha$ his $4-864$ ade $2-119$ irp5a leu2 & - \\
\hline$X X 1-1-5$ & a his $4-594$ ade $2-40$ irp5b cyh2 lysl & - \\
\hline $\mathrm{XXI}-\mathrm{I}-49$ & a his $4-594$ ade $2-40$ trp $5 b$ cyh 2 lys $l$ & - \\
\hline
\end{tabular}

Somatic hybridization by protoplast fusion in yeast is best explored by the use of genetically well marked strains of Saccharomyces cerevisiae permitting the selection of products and their unequivocal characterisation.

Intraspecific fusion of protoplasts of $\mathrm{S}$. cerevisiae of identical mating type has recently been reported by VAN SOLINGEN and VAN DER PlaAt (20), Ferenczy and Maráz (5) and Yamamoto and Fukui (25), whereas Stewart (21) reports on fusion of $S$. cerevisiae with $S$. carlsbergensis. With the aid of a detailed progeny analysis GUNGE and TAMARU (7) demonstrated that protoplast fusion of two $a$ strains of $\mathrm{S}$. cerevisiae gave rise to a regular diploid strain homozygous for the $a$ mating type gene: After mating the fusion product with an $\alpha \alpha$ diploid strain the tetrasomic inheritance of suitable markers was followed by tetrad analysis.

The present study has taken an analogous approach. One series of experiments involves cytoplasmic markers, the other involves fusion of two $a$ strains, fusion of two a strains and subsequent mating and tetrad analysis of the mating product.

\section{MATERIALS AND METHODS}

\subsection{Growth and medium}

Yeast cells to be converted into protoplasts were grown on a rotary shaker at $30^{\circ} \mathrm{C}$ in liquid YPD: 1\% Difco Bacto Yeast Extract, 2\% Difco Bacto Peptone, $2 \%$ glucose. Cells were har- vested in the logaritmic phase $\left(1-3 \times 10^{7}\right.$ cells $\cdot \mathrm{ml}^{-1}$ ) by centrifugation.

\subsection{Strains, crosses and genetic characterisa- tion}

The strains used in this study are shown in Table I. In the strains XXI-I-49, XXI-I-5, $\mathrm{XXa}-\mathrm{III}-7$ and XXa-I-9 the his4-594 and his 4-864 alleles complement as do ade2-40 and ade2-119. Strains carrying ade2-40 and ade119 are red and pink, respectively. There is no complementation between trp5 and trp5b. Strains D585-1 IC, D587-4B, D273-11 A and I)286-2A were used as mating type testers.

Crosses and tetrad analysis were carried out according to HAWTHORNE and MoRTIMER (11). Sporulation medium was $1 \%$ potassium acetate, $0.1 \%$ Difco Bacto Yeast Extract, $0.05 \%$ glucose, solidified with 2\% Difco Bacto Agar (1). Staining with malachite green - safranine (18) was used to detect sporulation.

Tests for resistance to erythromycin and chloramphenicol were performed on YPG ( $3 \%$ glycerol substituted for glucose in YPD) plates supplemented with $4 \mathrm{mg} \cdot \mathrm{ml}^{-1}$ erythromycin (Sigma) and $4 \mathrm{mg} \cdot \mathrm{ml}^{-1}$ chloramphenicol (Sigma), respectively (1).

Synthetic complete media and media for detection of nutritional requirements were $0.67 \%$ Difco Yeast Nitrogen Base without amino acids, $2 \%$ glucose, $2 \%$ Difco Bacto Agar, appropriately supplemented with nutrients as described by ZIMMERMANN (26). 


\subsection{Protoplast formation}

Protoplasts were made essentially according to the procedures of SCHWENCKE et al. (19) and Newlon and Fangman (16). Cells were harvested, washed twice in cold water and suspended in pretreatment buffer. In experiment 3.2 the buffer consisted of $0.2 \mathrm{~m}$-Tris, $0.02 \mathrm{~m}$-EDTA, $1.2 \mathrm{~m}$ sorbitol, $0.1 \mathrm{M}-\beta$-mercaptoethanol, $\mathrm{pH} 9.1$ and in experiment 3.3 the pretreatment was carried out in $5 \mathrm{~mm}$-EDTA, $50 \mathrm{~mm}$-dithiothreitol (DTT), $0.1 \mathrm{M}$-Tris- $\mathrm{HCl}$ and $1 \mathrm{mg} \cdot \mathrm{ml}^{-1}$ pronase (Sigma, type VI), pH 8.9. The pretreatment lasted for 15 $\min$ at $30^{\circ} \mathrm{C}$ and was followed by 3 washes with 1 M-sorbitol, 0.1 m-sodiumcitrate, $\mathrm{pH}$ unadjusted.

The cells were then treated at $30^{\circ} \mathrm{C}$ with snail gut enzymes in the same medium. In experiment 3.2 Suc d'Helix Pomatia (Industrie Biologique Française) was used at a concentration of $10 \%$ for 90-100 min with a cell density of $3 \times 10^{9}$ cells $\cdot \mathrm{ml}^{-1}$. In experiment $3.35 \%$ of a corresponding enzyme preparation ( $\beta$-glucuronidase/ arylsulfatase Boehringer) was used at a cell density of $5 \times 10^{8}$ cells $\cdot \mathrm{ml}^{-1}$ for $30 \mathrm{~min}$. The procedure for experiment 3.2 was initially also applied to the strains used in experiment 3.3, but the protoplast formation was very poor and slow $(200-300 \mathrm{~min})$. Protoplasts were collected by centrifugation and washed three times with sorbitol stabilizing buffer: $0.67 \%$ Difco Yeast Nitrogen Base, $1 \mathrm{~m}$-sorbitol, $10 \mathrm{~mm}-\mathrm{CaCl}_{2}$.

\subsection{Fusion procedure}

Fusion of the washed protoplasts was performed according to vaN SOLINGEN and VA.N DER PlaAT (20). Gently and slowly the protoplast pellet was suspended in $40 \% \mathrm{w} / \mathrm{v}$ polyethylene glycol 4000 (Merck), $10 \mathrm{~mm}-\mathrm{CaCl}_{2}, 10 \mathrm{~mm}$ Tris- $\mathrm{HCl}, \mathrm{pH} 7.5$, to a density of $5 \times 10^{7}-2$ $\times 10^{8}$ cells $\cdot \mathrm{ml}^{-1}$. The suspension was incubated with gentle shaking at $30^{\circ} \mathrm{C}$ for $30 \mathrm{~min}$. At this stage several forms of fusion products could be observed in the phase contrast microscope including large aggregations of protoplasts, huge heterocaryons of fused protoplasts and single giant cells made up of a few protoplasts. Polyethylene glycol was removed by washing 3 times with sorbitol stabilizing buffer, and appropriate dilutions were made.

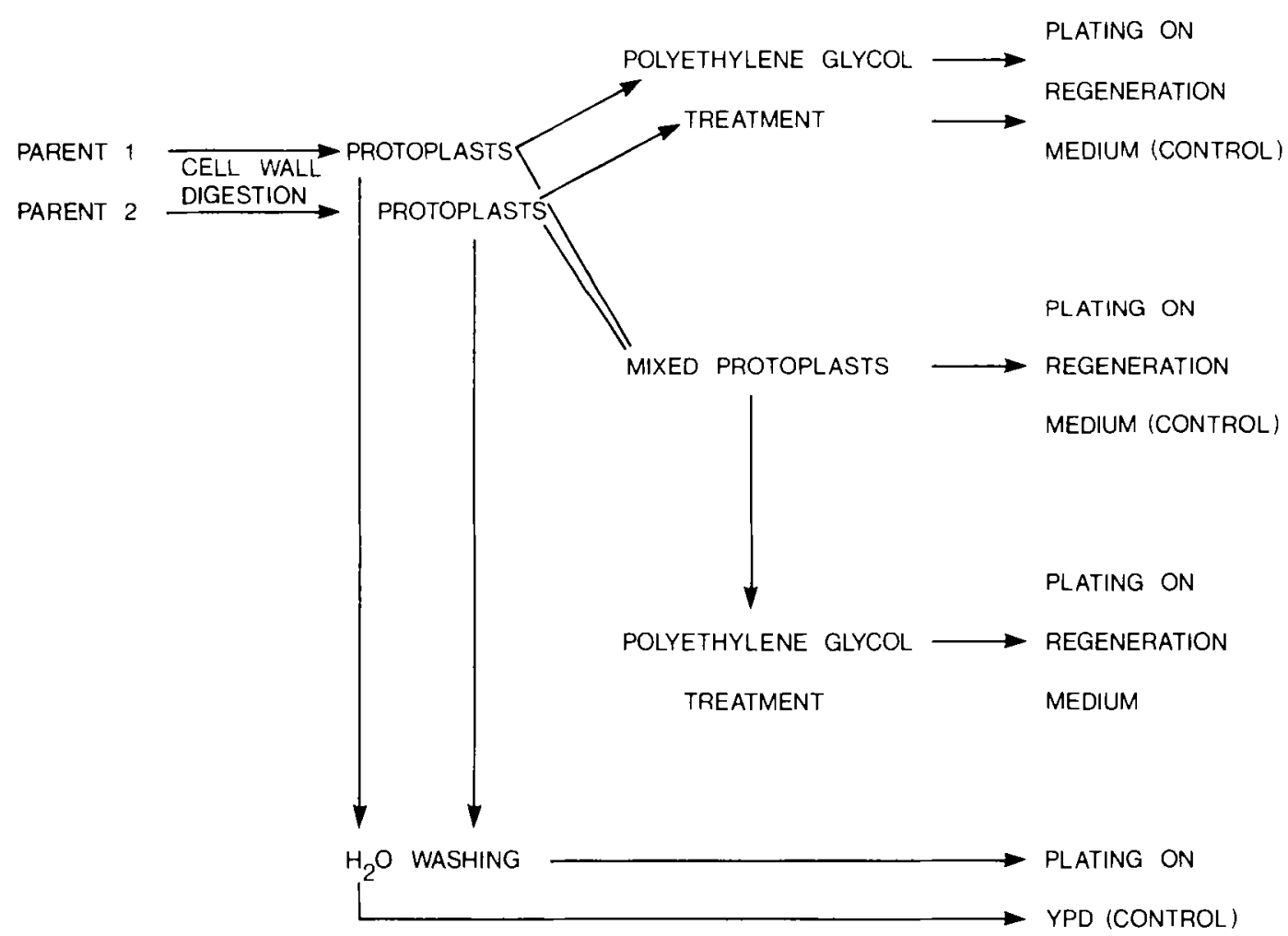

Figure 1. Flow diagram of the fusion experiments. 


\subsection{Regeneration of the fused protoplasts}

$0.1 \mathrm{ml}$ of fusion products in sorbitol stabilizing buffer was placed on a supplemented or non-supplemented regeneration plate (22): $0.67 \%$ Yeast Nitrogen Base without amino acids, I M-sorbitol, 3\% Difco Bacto Agar, 2\% glucose. $1.5 \mathrm{ml}$ hot $3.2 \%$ Difco Bacto Agar, 1 $\mathrm{M}$-sorbitol from a boiling waterbath was placed in a ring around the droplet, and with a Drigalski spreader, agar and fused protoplasts were mixed quickly, in such a way that solidification took place in a few seconds (6). A flow diagram of the actual fusion experiments and the three controls is presented in Figure $\mathrm{I}$.

\section{RESULTS}

\subsection{Protoplasting efficiency and regeneration frequency}

Protoplasts were suspended in and washed two times with water and then plated on YPD plates. Only cells osmotically stable will turn into colonies, which gives a measure of the efficiency of the protoplasting treatment. The results are shown in Table II. Protoplasting efficiency is better than or equal to $10^{6}$ protoplasts per intact cell.

Good regeneration is required for the efficient recovery of somatic hybrids. Table II includes the regeneration frequencies of the protoplasts plated on a complete regeneration medium after treatment with polyethylene glycol. The regeneration frequency ranges from $0.03 \%$ to $20 \%$, the variation probably being due to strain differences as well as differences in the procedure. Especially the extent of snail gut enzyme treatment can be critical.

\subsection{Fusion involving cytoplasmic markers}

Protoplasts of the auxotrophic strains D5174B a ade2 lys 9 and C77-D2 a his3 leu2 trp ERY ${ }^{R}$ CAPR were mixed, treated with polyethylene glycol 4000 and plated for regeneration on minimal medium. After two to three days prototrophic colonies appeared (Table III). When parent strains were treated separately with polyethylene glycol and plated on minimal medium no prototrophic colonies were observed indicating that the polyethylene glycol treatment does not cause the appearance of prototrophic colonies. Likewise when the mixture of D517$4 B$ and $C 77-D 2$ protoplasts was plated without polyethylene glycol treatment prototrophic colonies were absent. Normal mating was thus not the cause for the occurrence of the prototrophic colonies. None of the fusion products sporulated (149 tested), and all had the expected $a$ mating type ( 71 tested). As one of the parents, C77-D2. carried the cytoplasmic genes for resistance to erythromycin and chloramphenicol, the behaviour of the fusion products towards these drugs was tested. As seen in Table IV the tested progenies comprised the four possible combinations of the two markers. About $10 \%$ of the progeny were recombinant for the cytoplasmatic markers. This reveals that the cytoplasmic markers segregated and recombined in the same way as is observed after mating (24).

\section{Table II}

Regeneration frequencies of yeast protoplasts from the different strains used in fusion experiments

\begin{tabular}{|c|c|c|c|c|c|}
\hline \multirow[b]{2}{*}{ Strain } & \multicolumn{2}{|c|}{$\begin{array}{l}\text { Washing of protoplasts in water } \\
\text { and plating on YPD }\end{array}$} & \multicolumn{3}{|c|}{$\begin{array}{l}\text { Embedding of protoplasts for regeneration } \\
\text { in complete medium }\end{array}$} \\
\hline & $\begin{array}{l}\text { Number of } \\
\text { protoplasts }\end{array}$ & $\begin{array}{l}\text { Number of } \\
\text { colonies }\end{array}$ & $\begin{array}{l}\text { Number of } \\
\text { protoplasts }\end{array}$ & $\begin{array}{l}\text { Number of } \\
\text { colonies }\end{array}$ & $\begin{array}{l}\text { Regeneration } \\
\text { frequency (per cent) }\end{array}$ \\
\hline $\mathrm{C} 77-\mathrm{D} 2$ & $4 \times 10^{7}$ & 0 & $2,5 \times 10^{3}$ & $5 \times 10^{2}$ & 20 \\
\hline D5 $17-4 B$ & $4 \times 10^{6}$ & 1 & $8 \times 102$ & 84 & 10.5 \\
\hline XXI-I-49 & $1 \times 10^{6}$ & 0 & $3 \times 10^{7}$ & 104 & 0.03 \\
\hline XXI-I-5 & $1 \times 106$ & 0 & $2 \times 10^{7}$ & 104 & 0.05 \\
\hline XXa-III-7 & $1 \times 10^{6}$ & 0 & $3 \times 10^{5}$ & 300 & 0.1 \\
\hline XXa-I-9 & $1 \times 10^{6}$ & 0 & $2 \times 10^{7}$ & 104 & 0.05 \\
\hline
\end{tabular}


Table III

Fusion experiment involving cytoplasmic markers

$\begin{array}{llll}\text { D517-4B: } & +a & \underline{\text { lys } 9} \pm \underline{a d e 2+} \\ \mathrm{C} 77-\mathrm{D} 2: & \underline{\text { leut } a}+\underline{t r p}+\text { his } 3 & \end{array}$

\begin{tabular}{lcccr}
\hline & D517-4B & C77-D2 & D517-4B + C77-D2 \\
\hline Polyethylene glycol treatment & + & + & - & + \\
\hline Protoplasts plated on minimal medium & $4.7 \times 10^{7}$ & $1.7 \times 10^{7}$ & $\begin{array}{r}1.2 \times 10^{7} \\
+1.2 \times 10^{7}\end{array}$ \\
\hline Number of colonies & 0 & 0 & 0 & $\begin{array}{r}2 \times 10^{8} \\
+2 \times 10^{8}\end{array}$ \\
\hline
\end{tabular}

\subsection{Fusion of his 4 and ade 2 complementing strains}

Protoplasts of the two a mating type strains XXI-I-49 a his4-594 ade2-40 trp5b cyh2 lysl and XXa-I-9 a his4-864 ade2-119 trp5a leu2 ilv I were fused. As the two his 4 mutant alleles and the two ade 2 mutant alleles complement somatic hybrids were selected by plating on minimal medium supplemented with tryptophane.

Likewise the two $\alpha$ mating type strains XXII-5 a his4-594 ade2-40 trp5b cyh2 lysl and XXa-III-7 a his4-864 ade2-119 trp5a leu2 were fused.

Table V shows that several hundred colonies were obtained in both experiments with none of the controls giving rise to colonies. Of 244 tested fusion products all were found to be homozygous for the mating type gene, since they could only sporulate after mating with the opposite mating type.

\subsection{Genetic analysis of fusion products from the his 4 and ade 2 complementing strains}

The genetic analysis of the somatic hybrids was carried out according to Figure 2: After mating of two fusion products the tetraploid was propagated and sporulated. Individual asci were dissected and the individual diploid spores grown and tested for their capability to sporulate. Only spores of the $a \alpha$ genotype yield cultures capable of sporulating without previous mating.

In this way a tetrad was selected which had yielded four $a \alpha$ clones. Asci from these clones contain haploid spores, which were dissected out and analysed for the auxotrophic and cycloheximide resistent markers. From these tetrad analyses the genotypes of the diploid spores could be determined and these are listed in Table VI for two pairs of fusion products.

In the first case the expected segregation for all testable markers is obtained which proves that the mating product indeed was a tetraploid containing all chromosomes of the parents XXII-5, XXI-I-49, XXa-I-9 and XXa-III-7, and that the fusion products were diploid.

In the second case also a perfect segregation is observed for all markers with the exception of the leucine 2 gene where a $6: 2$ instead of a $4: 4$ segregation is observed. This exceptional segregation must be due to a gene conversion or a mitotic crossing over and not due to aneuploidy of chromosome III since the mating type locus on the same chromosome segregates regularly.

\section{Table IV}

Resistance to erythromycin and chloramphenicol of 152 fusion products

\begin{tabular}{lcccc}
\hline & ERYSCAPS & ERYRCAPS & ERYSCAPR & ERYRCAPR \\
\hline Number of colonies & 72 & 7 & 10 & 63 \\
\hline
\end{tabular}


B. E. Christensen: Somatic hybridization in yeast

Table V

Somatic hybridization by protoplast fusion of yeast strains carrying complementing auxotrophic markers

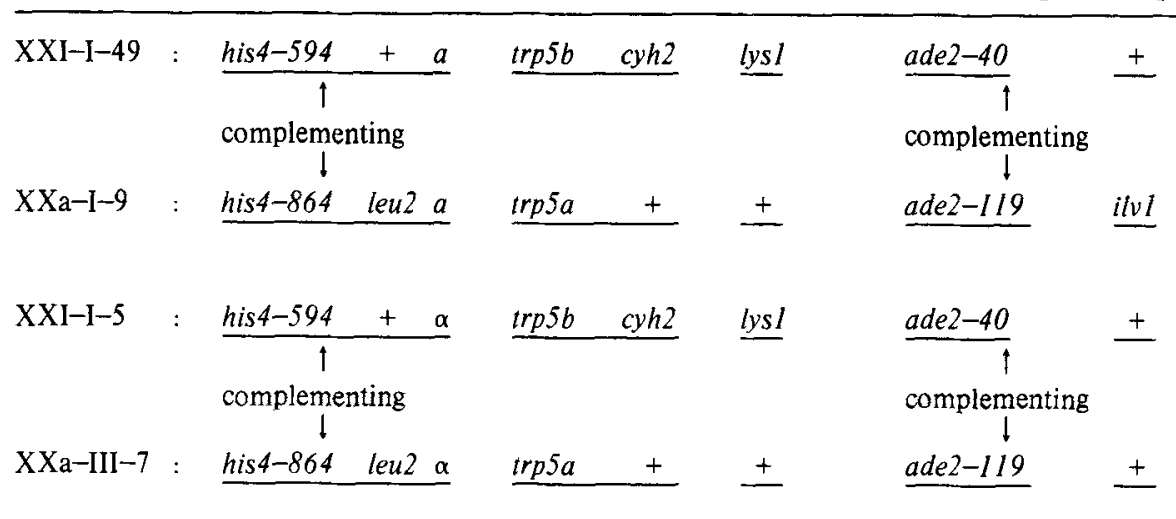

XXI-I-49 XXI-I-5 XXa-III-7 XXa-I-9 XXI-I-49+XXa-I-9 XXI-I-5 + XXa-III-7

\begin{tabular}{l}
$\begin{array}{l}\text { Polyethylene } \\
\text { glycol } \\
\text { treatment }\end{array}++++$ \\
\hline
\end{tabular}

Number plated on minimal regeneration medium supplemented with

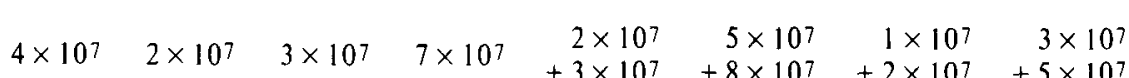
tryptophan

Number of colonies 0

0

0

0
$\sim 800$ 0 714

\section{DISCUSSION}

Intact yeast cells of like mating type do not exchange genetic material, but when a mixture of protoplasts of two different auxotrophic strains of identical mating type were treated with polyethylene glycol, recombinant cells arose in which the fusion partners had complemented each others deficiencies.

The data in Tables III and V give a statistical argument that the prototrophs were indeed somatic hybrids: The appearance of wild type colonies was not due to reversion of markers in the parent strains; since in that case single polyethylene glycol treated parents would have given colonies on selective regeneration medium. Likewise, mating may be ruled out because of absence of colonies on regeneration plates inoculated with mixed parents which had not been in contact with polyethylene glycol. More important than the statistical argument however, is the genetic analysis of the products. The possibility that substances present in the polyethylene glycol might have acted mutagenically on the mating type locus and thereby enabled ceils to mate, would imply sporulation of the products, but this was not found. Furthermore segregation of mating type alleles in the tetrad analysis shows the expected 4:4 ratio.

If the fusion products are assumed to be diploid, mating between the fusion products of opposite mating type will lead to a tetraploid. When these $a / a / \alpha / \alpha$ cells are induced to sporulate, three types of diploid spores are expected to arise, $a / a$ and $\alpha / \alpha$ spores which do not sporulate and $a / \alpha$ which can be induced to go through meiosis. Tetrads should be frequent in which all four spores are $a / \alpha(17)$. Such two tetrads were subjected to further analysis by 


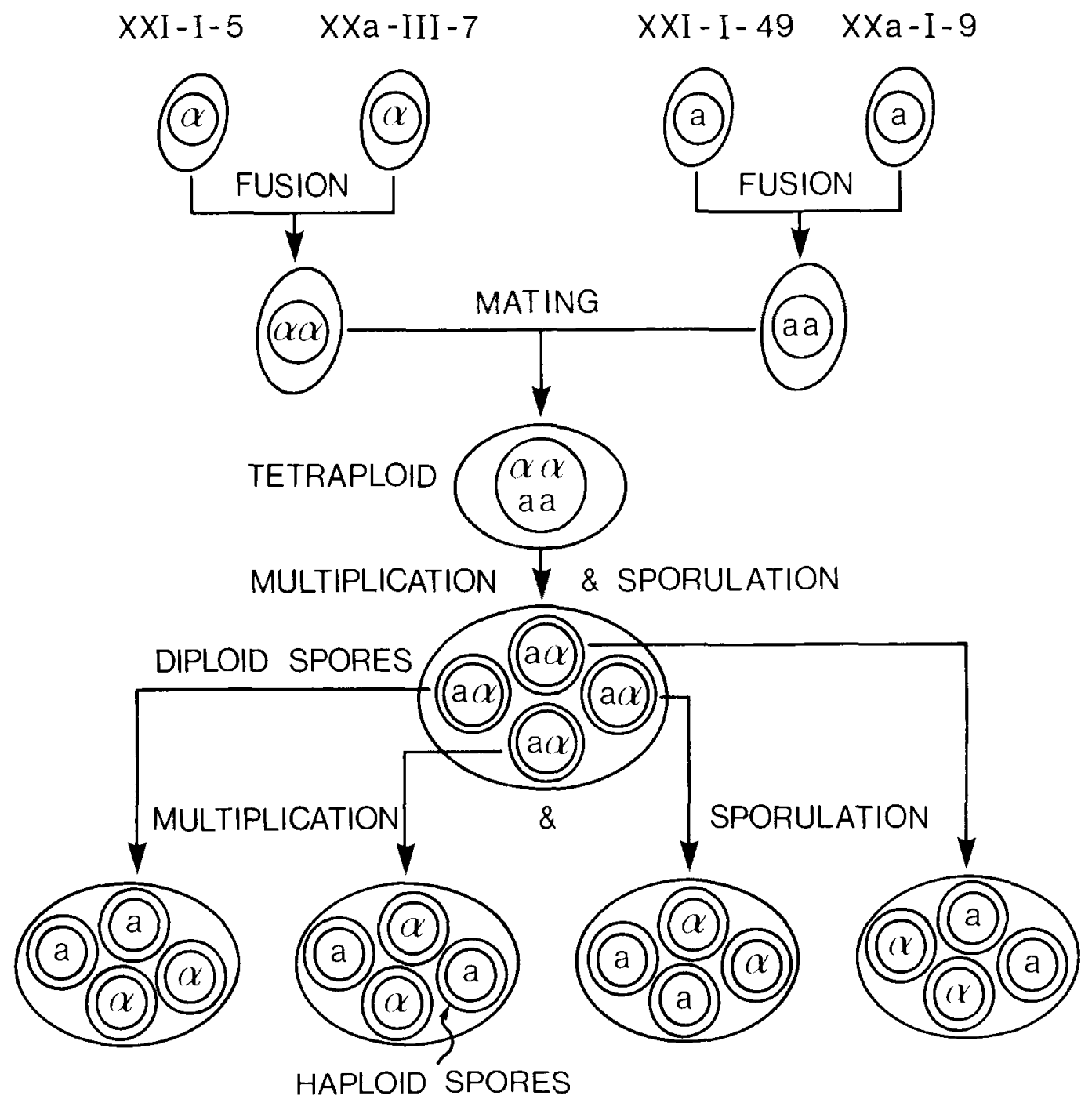

Figure 2. Diagram of the steps involved in the genetic analysis of the fusion products presented in Tables $V$ and VI.

sporulation and tetrad analysis. All but one of the markers segregated in the expected ratios $2: 6$ for ilvl and $4: 4$ for the others. The one odd segregation of leu 2 in the second tetrad must be due to a gene conversion or mitotic crossing over, and not aneuploidy, since the mating type alleles on the same chromosome segregated regularly.

Products from the fusion of C77-D2 carrying [ERYR ${ }^{R}{ }^{2} P^{R}$ ] and D517-4B will be expected to show resistance to erythromycin and chloram- phenicol. Indeed when tested against these drugs recombinants [ERYSCAPR] and [ERYRCAPS] were found thus confirming the assumption of fusion.

Neither in the study of GUNGE and TAMaru (7) nor in the present study is there reason to believe that aneuploidy occurred for any of the unmarked chromosomes. I conclude that not only $a+a$ fusions (7) but also $\alpha+\alpha$ fusions can give rise to regular diploids homozygous for the mating type locus. 
B. E. Christensen: Somatic hybridization in yeast

\section{Table VI}

Genetic analysis of two pairs of protoplast products by the procedure outlined in Figure 2

Expected genotypes of the fusion products:

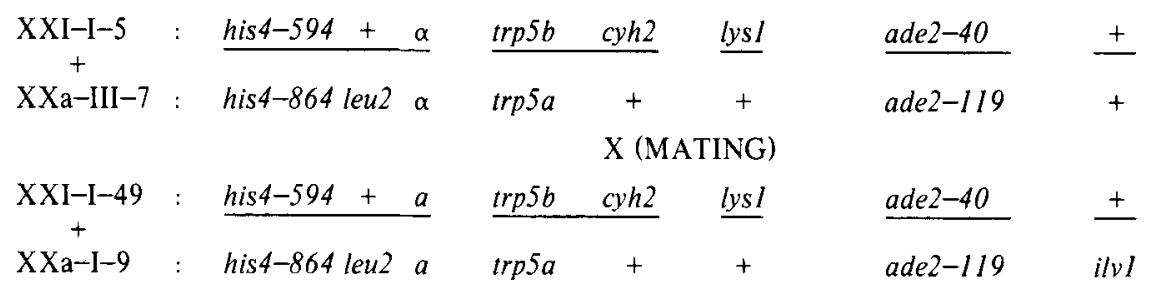

Genotypes of the diploid spores in the 2 experiments:

\begin{tabular}{|c|c|c|c|c|c|c|c|c|c|c|}
\hline \multirow[t]{2}{*}{ Spore 1} & $:$ & his 4 & + & $a$ & trp5 & $c y h 2$ & lysl & ade $2-40$ & + & 12 \\
\hline & & his 4 & leu 2 & $\alpha$ & $\operatorname{trp} 5$ & + & + & ade $2-119$ & + & \\
\hline \multirow[t]{2}{*}{ Spore 2} & : & his4 & + & $\underline{a}$ & $\operatorname{trp} 5$ & $c y h 2$ & $\underline{|y s|}$ & ade $2-40$ & ilvI & 3 \\
\hline & & his 4 & leu2 & $\alpha$ & trp5 & + & $|y s|$ & ade2-119 & + & \\
\hline \multirow[t]{2}{*}{ Spore 3} & : & his4 & leu 2 & $\underline{a}$ & trp5 & $c y h 2$ & |ys & ade 2-40 & $i|v|$ & 6 \\
\hline & & his4 & + & $\alpha$ & $\operatorname{trp} 5$ & + & + & ade $2-119$ & + & \\
\hline \multirow[t]{2}{*}{ Spore 4} & $:$ & his4 & leu2 & $a$ & $\operatorname{trp} 5$ & cyh2 & + & ade2-40 & + & 18 \\
\hline & & his 4 & + & $\alpha$ & $\operatorname{trp} 5$ & + & + & ade2-119 & + & \\
\hline \multicolumn{2}{|l|}{ Segregation: } & & $4: 4$ & $4: 4$ & & $4: 4$ & $4: 4$ & $4: 4$ & $6: 2$ & \\
\hline \multirow[t]{2}{*}{ Spore 1} & : & his4 & + & $\underline{a}$ & $\operatorname{trp} 5$ & cyh2 & $\underline{|y s|}$ & ade2 -40 & + & 5 \\
\hline & & his 4 & + & $\alpha$ & trp 5 & $c y h 2$ & + & ade2 -119 & + & \\
\hline \multirow[t]{2}{*}{ Spore 2} & $:$ & his4 & + & $\underline{a}$ & $\operatorname{trp} 5$ & + & + & ade $2-40$ & + & 6 \\
\hline & & his 4 & + & $\alpha$ & $\operatorname{trp} 5$ & + & + & ade2-119 & + & \\
\hline \multirow[t]{2}{*}{ Spore 3} & $:$ & his 4 & leu2 & $\underline{a}$ & trp5 & + & $\underline{l y s I}$ & ade $2-40$ & $\underline{i l v I}$ & 7 \\
\hline & & his4 & + & $\alpha$ & $\operatorname{trp} 5$ & + & $|y s|$ & ade $2-119$ & + & \\
\hline \multirow[t]{2}{*}{ Spore 4} & $:$ & his4 & leu2 & $\underline{a}$ & trp5 & cyh2 & lysI & ade $2-40$ & ilvl & 7 \\
\hline & & his 4 & + & $\alpha$ & $\operatorname{trp} 5$ & cyh2 & + & ade2-119 & + & \\
\hline Segregation & & & $6: 2$ & $4: 4$ & & $4: 4$ & $4: 4$ & $4: 4$ & $6: 2$ & \\
\hline
\end{tabular}

\section{ACKNOWLEDGEMENT}

The encouragement from and helpful discus- SON-Tillgren, cand. polyt. Jens Litske Petersions with professor Diter von Wettstein, Dr. SEN, cand. scient. Steen Holmberg and Dipl. Morten Kielland-Brandt, Dr. Torsten Nils- Biol. Barbara Wilken are greatly appreciated. 


\section{REFERENCES}

1. Course manual on yeast genetics, Cold Spring Harbor Laboratory (1974)

2. Eddy, A. A. \& D. H. Williamson: A method of isolating protoplasts from yeast. Nature 179 , 1252-1253(1957)

3. EmeIs, C. C.: Haploidisierung von diploiden Hefen durch p-Flouro-Phenylalanine. Z. Naturforsch. 21, 816-817 (1966)

4. Emerson, S.: Notes of the identification of different cases of aberrant tetrad ratios in Saccharomyces. Compt. Rend. Lab. Carlsberg, Ser. Physiol. 26, 71-86 (1956)

5. Ferenczy, L. \& A. Maráz: Transfer of mitochondria by protoplast fusion in Saccharomyces cereviseae. Nature 268, 524-525 (1977)

6. Fukui, K., Y. Sagara, N. Yoshida \& T. MATSUOKA: Analytical studies on regeneration of Geotrichum candidum by quantitative thinlayer-agar plating. J. Bacteriol. 98, 256-263 (1969)

7. Gunge, N. \& A. Tamaru: Genetic analysis of products of protoplast fusion in Saccharomyces cereviseae. Japan J. Genetics 53, 41-49 (1978)

8. Gutz, H.: Induction of mitotic segregation with p-flourophenylalanine in Schizosaccharomyces pombe. J. Bacteriol 92, 1567-1568 (1966)

9. KAO, K. N. \& M. R. MichayluK: A method for high-frequency intergenic fusion of plant protoplasts. Planta 115, 355-367 (1974)

10. Lhoas, P.: Mitotic haploidisation by treatment of Aspergillus niger diploids with para-fluorophenylalanine. Nature 190, 744 (1961)

11. Hawthorne, D. C. \& R. K. Mortimer: Chromosome mapping in Saccharomyces: centromere-linked genes. Genetics 45, 1085-1110 (1960)

12. NečAs, O.: Regeneration of yeast cells from naked protoplasts. Nature 177, 898-899 (1956)

13. NečAs, O.: Physical conditions as important factors for the regeneration of naked yeast protoplast. Nature 192, 580-581 (1961)

14. NEČAs, O.: The mechanism of regeneration of yeast protoplasts. I. Physical conditions. Folia Biologica (Praha) 8, 256-262 (1962)
15. NEČAS, O.: The mechanism of regeneration of yeast protoplasts. II Formation of cell wall de novo. Folia Biologica (Praha) 11, 97-102 (1965)

16. Newlon, C. S. \& W. L. Fangman: Mitochondrial DNA synthesis in cell cycle mutants of Saccharomyces cereviseae. Cell 5, 423-428 (1977)

17. Roman, H., M. M. Phillips \& S. S. Sands: Studies of polyploid Saccharomyces. I. Tetraploid segregation. Genetics 40, 546-561 (1955)

18. Schaeffer, A. B. \& M. Futton: A simplified method of staining endospores. Science 77, 194 (1933)

19. Schwencke, J., N. Magaña-Schwencke \& J. LAPORTE: Yeast protoplasts from stationary and starved cells: Preparation, ultrastructure and vacuolar development. Annales de Microbiologie 128, 3-18 (1977)

20. Solingen, P. van \& J. B. van der Plaat: Fusion of yeast spheroplasts. J. Bacteriol. 1 30, 946-947 (1977)

21. Stewart, G. G.: Application of yeast genetics within the brewing industry. ASBC Journal 36 , 175-185 (1978)

22. Svoboda, A.: Regeneration of yeast protoplasts in agar gels. Exp. Cell Res. 44, 640-642 (1966)

23. Wettstein, D. von: Biochemical and molecular genetics in the improvement of malting barley and brewers yeast. Proc. Europ. Brewery Conv. Congr. Berlin 1979, in press.

24. WilkiE, D.: Cytoplasmatic inheritance and mitochondrial genetics in yeast. Meth. Cell Biol. XII, 353-372 (1975)

25. Yамамото, M. \& S. Fukul: Fusion of yeast protoplasts. Agric. Biol. Chem. 41, 1829-1830 (1977)

26. ZimmermanN, F. K.: Detection of genetically active chemicals using various yeast systems. In: Chemical Mutagens. Principles and methods for their detection. A. Hollaender ed., Plenum Press. New York - London, vol III pp 209-239 (1973) 